Article

\title{
Development of $\mathrm{TiO}_{2}$-Carbon Composite Acid Catalyst for Dehydration of Fructose to 5-Hydroxymethylfurfural
}

\author{
Morongwa Martha Songo ${ }^{1,2}$, Richard Moutloali ${ }^{2}$ and Suprakas Sinha Ray ${ }^{1,2, *(D)}$ \\ 1 DST-CSIR National Centre for Nanostructured Materials, Council for Scientific and Industrial Research, \\ Pretoria 0001, South Africa; msongo@csir.co.za \\ 2 Department of Applied Chemistry, University of Johannesburg, Doornfontein, Johannesburg 2028, \\ South Africa; rmoutloali@uj.ac.za \\ * Correspondence: rsuprakas@csir.co.za; Tel.: +27-12-841-2388
}

Received: 28 December 2018; Accepted: 29 January 2019; Published: 31 January 2019

\begin{abstract}
A} \mathrm{TiO}_{2}$-Carbon $\left(\mathrm{TiO}_{2} \mathrm{C}\right)$ composite was prepared using the microwave-assisted method and sulfonated using fuming sulfuric acid to produce a $\mathrm{TiO}_{2} \mathrm{C}$ solid acid catalyst. The prepared solid acid catalyst was characterised using scanning electron microscopy, Brunauer-Emmett-Teller analysis, Fourier transform infrared spectroscopy, and X-ray diffraction. Crystallinity analysis confirmed that $\mathrm{TiO}_{2} \mathrm{C}$ has an anatase structure, while analysis of its morphology showed a combination of spheres and particles with a diameter of $50 \mathrm{~nm}$. The $\mathrm{TiO}_{2} \mathrm{C}$ solid acid catalyst was tested for use in the catalytic dehydration of fructose to 5-hydroxymethylfurfural (5-HMF). The effect of reaction time, reaction temperature, catalyst dosage, and solvent were investigated against the 5-HMF yield. The 5-HMF yield was found to be $90 \%$ under optimum conditions. The solid acid catalyst is very stable and can be reused for four catalytic cycles. Hence, the material has great potential for use in industrial applications and can be used for the direct conversion of fructose to 5-HMF because of its high activity and high reusability.
\end{abstract}

Keywords: $\mathrm{TiO}_{2} \mathrm{C}$ composite; acid catalyst; dehydration; fructose; 5-Hydroxymethylfurfural

\section{Introduction}

Increase in the usage of fossil fuels for the production of chemicals and energy has caused not only a rise in greenhouse gas emissions into the atmosphere, but also water pollution, thereby contributing to the growing number of serious health issues. These side effects have spurred researchers to look for alternative ways of producing valuable chemicals and energy using sustainable and renewable resources. Biomass has been identified as a promising resource for the sustainable production of valuable chemical feedstocks and fuels [1]. 5-hydroxymethylfurfural (5-HMF) has been recognised as a key intermediate in the production of biorenewable chemicals [2] and has been classified as a "platform molecule" because it is an important chemical building block used to derive a variety of chemicals, pharmaceuticals, and furane-based polymers [3].

5-HMF is usually synthesised from the dehydration of fructose or glucose using homogeneous organic acids or heterogeneous solid acid catalysts [4]. Although the use of homogeneous catalysts produces high fructose conversion and high dehydrations of 5-HMF, there are drawbacks with regard to separation, recycling, and equipment corrosion [5,6]. Heterogeneous acid catalysts such as mesoporous zirconium phosphate [7,8], sulfonated metal oxides [9], magnetite mixed-metal oxides [10], and functionalised silica nanoparticles [11,12] have been used for the dehydration of fructose to 5-HMF. Although the use of some of these materials has promising results, the studies cited pointed out the 
remaining challenge of finding catalysts that are highly active, selective, chemically and structurally stable during repeated use, and do not lead to any side reactions (by-products). Biomass-derived carbonaceous materials were found to be promising candidates for catalytic support application because of their low cost of production and thermal stability [13]. For example, Wang et al. [14] used a sulfonated carbonaceous solid acid catalyst for the dehydration of fructose into 5-HMF in dimethyl sulfoxide (DMSO). Their catalyst was very efficient and effective in that it converted $96.1 \%$ of the fructose for a high 5-HMF yield of $93.4 \%$. Zhao et al. [15] further explored a sulfonated carbon sphere solid acid catalyst that converted $100 \%$ of the fructose in DMSO solvent at $160{ }^{\circ} \mathrm{C}$ for $1.5 \mathrm{~h}$ to produce 90\% 5-HMF. Wang et al. [16] used C-based solid acid catalysts to catalyse dehydration of fructose in DMSO for $1.5 \mathrm{~h}$ at $130{ }^{\circ} \mathrm{C}$ to achieve 91.2\% 5-HMF. Guo et al. [17] used a lignin-derived carbonaceous catalyst to convert fructose into 5-HMF under microwave irradiation in the mixture of DMSO and ionic liquid at $110{ }^{\circ} \mathrm{C}$ for $10 \mathrm{~min}$ for a fructose conversion of $98 \%$ and a 5-HMF yieldof $84 \%$. Hu et al. [18] explored the use of a magnetic lignin-derived carbonaceous acid catalyst for the catalytic conversion of fructose into 5-HMF in DMSO solvent. Use of the magnetic C-based catalyst achieved a $100 \%$ fructose conversion and a $5-\mathrm{HMF}$ yieldof $81.1 \%$ under optimum reaction conditions.

Studies have found that the anatase phase of $\mathrm{TiO}_{2}$ can catalyse the dehydration of carbohydrates such as fructose and glucose into 5-HMF and that the performance of the $\mathrm{TiO}_{2}$ catalyst is strongly controlled by its morphological and structural properties [3,19-21]. For example, the use of nanostructured $\mathrm{TiO}_{2}$ remarkably favoured the production of 5-HMF from glucose and fructose $[19,20]$, with its high activity being ascribed to the morphology of the nanoparticles [20].

In this paper, we report the synthesis, characterisation, and application of $\mathrm{TiO}_{2}$-Carbon sphere $\left(\mathrm{TiO}_{2} \mathrm{C}\right)$ composite for the catalysis of the dehydration of fructose into 5-HMF in DMSO solvent. To the best of our knowledge, there have been no reports on the use of $\mathrm{TiO}_{2} \mathrm{C}$ as a catalyst for the dehydration of fructose into 5-HMF. We synthesised the $\mathrm{TiO}_{2} \mathrm{C}$ composites using a microwave-assisted method. Because $\mathrm{TiO}_{2}$ has redox acidic sites, Bronsted acid sites were introduced by sulfonating the $\mathrm{TiO}_{2} \mathrm{C}$ composites with concentrated sulfuric acid. Scanning electron microscopy (SEM), Brunauer-Emmett-Teller (BET) analysis, X-ray diffraction, and Fourier transform infrared (FTIR) spectroscopy were used to characterise the $\mathrm{TiO}_{2} \mathrm{C}$ acid catalyst. This solid acid catalyst was tested in DMSO solvent as a catalyst for the dehydration of fructose into 5-HMF. To achieve a higher dehydration of 5-HMF, reaction parameters such as reaction temperature, reaction time, and catalyst amount were optimised. Moreover, the ability to recycle the catalyst was studied to evaluate its catalytic stability.

\section{Experimental and Methods}

\subsection{Materials}

All chemicals used for synthesising the $\mathrm{TiO}_{2}$ nanoparticles (NPs) and $\mathrm{TiO}_{2} \mathrm{C}$ composites were purchased from Sigma-Aldrich Corporation (St. Louis, MO, USA). Titanium (IV) isopropoxide (TTIP) and fructose were used as precursors in the preparation of $\mathrm{TiO}_{2}$ and $\mathrm{TiO}_{2} \mathrm{C}$ composites. Polyvinylpyrrolidone (PVP) was used as a surfactant and ammonium hydroxide was used as a reducing agent for the preparation of $\mathrm{TiO}_{2} \mathrm{NPs}$. Sulfuric acid was used for sulfonating the $\mathrm{TiO}_{2} \mathrm{C}$ solid acid catalyst.

\subsection{Preparation of $\mathrm{TiO}_{2}$ Nanoparticles Using the Sol-Gel Method}

Ethanol $(50 \mathrm{~mL})$ was mixed with $17.79 \mathrm{~g}$ of TTIP and stirred for $30 \mathrm{~min}$. PVP $(4 \mathrm{~g})$ was added to the mixture, which then was stirred at $70{ }^{\circ} \mathrm{C}$ until it was completely dissolved. Next, $4 \mathrm{~mL}$ of $\mathrm{NH}_{3} \cdot 2 \mathrm{H}_{2} \mathrm{O}$ was added. The solution was heated at $90^{\circ} \mathrm{C}$ under reflux conditions for $24 \mathrm{~h}$. The resultant sample was washed with water and dried at $100^{\circ} \mathrm{C}$ for $24 \mathrm{~h}$. 


\subsection{Preparation of Carbon Spheres Using the Microwave-Assisted Method}

The carbon precursor (fructose) was mixed with deionised (DI) water and stirred at room temperature $\left(25\right.$ to $27^{\circ} \mathrm{C}$ ) for $2 \mathrm{~h}$. The obtained mixture was transferred into microwavable plastic vessels that were then placed into the ultraclave high-performance microwave reactor and allowed to react at $180^{\circ} \mathrm{C}$ for $2 \mathrm{~h}$.

\subsection{Preparation of $\mathrm{TiO}_{2} \mathrm{C}$ Composites Using the Microwave-Assisted Method}

$\mathrm{TiO}_{2}$ nanoparticles were added to $50 \mathrm{~mL}$ of DI water. The solution was sonicated at $30{ }^{\circ} \mathrm{C}$ for at least $1 \mathrm{~h}$, after which the fructose was added. The $\mathrm{pH}$ of the solution was adjusted to 2 . The solution was stirred at room temperature $\left(25\right.$ to $\left.27^{\circ} \mathrm{C}\right)$ for $2 \mathrm{~h}$ and then microwaved in the ultraclave high-performance microwave reactor for another $2 \mathrm{~h}$ at $180^{\circ} \mathrm{C}$. The resultant sample was washed three times with DI water, dried at $150{ }^{\circ} \mathrm{C}$ for $24 \mathrm{~h}$, and then calcined at $500{ }^{\circ} \mathrm{C}$ for $2 \mathrm{~h}$. Different amounts of $\mathrm{TiO}_{2}$ nanoparticles $(1,5$, and $10 \%)$ were loaded onto the carbon spheres. For example, to prepare the $1 \% \mathrm{TiO}_{2} \mathrm{C}$ nanocomposite, $0.1 \mathrm{~g}$ of $\mathrm{TiO}_{2}$ nanoparticles was added to $9.9 \mathrm{~g}$ of fructose, whereas to prepare the $5 \% \mathrm{TiO}_{2} \mathrm{C}$ and $10 \% \mathrm{TiO}_{2} \mathrm{C}$, the mass ratio of $\mathrm{TiO}_{2}$ nanoparticles to fructose was 0.5:9.5 and 1:9, respectively. The $\mathrm{TiO}_{2} \mathrm{C}$ composites loaded with 1,5 , and $10 \% \mathrm{TiO}_{2}$ were denoted as $1 \% \mathrm{TiO}_{2} \mathrm{C}, 5 \% \mathrm{TiO}_{2} \mathrm{C}$, and $10 \% \mathrm{TiO}_{2} \mathrm{C}$, respectively.

\subsection{Preparation of the Sulfonated Carbon and $\mathrm{TiO}_{2} \mathrm{C}$ Acid Catalysts}

$\mathrm{TiO}_{2} \mathrm{C}$ was sulfonated by adding $1 \mathrm{~g}$ of $\mathrm{TiO}_{2} \mathrm{C}$ composite to $25 \mathrm{ml}$ of concentrated sulfuric acid and stirring the solution at $120^{\circ} \mathrm{C}$ for $24 \mathrm{~h}$ under reflux conditions. The sulfonated samples, denoted as $\mathrm{TiO}_{2} \mathrm{C} \_\mathrm{S}$, were washed with DI water and dried at $150^{\circ} \mathrm{C}$ for $24 \mathrm{~h}$. The carbon spheres were sulfonated using the same method and were denoted as C_S.

\subsection{Surface Acid Measurement Tests}

A total of $100 \mathrm{mg}$ of $\mathrm{C} \_\mathrm{S}$ and $\mathrm{TiO}_{2} \mathrm{C} \_\mathrm{S}$ composite acid catalysts was mixed with $50 \mathrm{ml}$ of DI water and $40 \mathrm{ml}$ of $0.01 \mathrm{M} \mathrm{NaOH}$ and stirred at room temperature $\left(25\right.$ to $\left.27^{\circ} \mathrm{C}\right)$ overnight [22]. The solution was filtered and titrated with $0.1 \mathrm{~N}$ of oxalic acid using phenolphthalein as the indicator.

\subsection{Characterisation}

Elemental composition and surface morphology analyses were conducted using the AURIGA ${ }^{\circledR}$ scanning electron microscope (Zeiss, Oberkochen, Germany). The crystallinity and phase composition were investigated using the PanAlytical X'Pert Pro (Panalytical Ltd., Eindhoven, The Netherlands). The functional groups of the catalysts were measured in the wavelength range of $550-4000 \mathrm{~cm}^{-1}$ using a Spectrum 100 FTIR spectrometer (PerkinElmer, Waltham, MA, USA). The specific surface area, pore volume, and pore size were measured using the ASAP 2020 BET analysis system (Micromeritics Instruments Corp., Norcross, GA, USA).

\subsection{Catalytic Testing}

Fructose $(0.5 \mathrm{~g})$, DMSO $(6 \mathrm{ml})$, and catalyst $(0.1 \mathrm{~g})$ were placed in a vessel and allowed to react for $1 \mathrm{~h}$ at $120^{\circ} \mathrm{C}$ using the ultraclave high-performance microwave reactor. After the reaction, the solution was centrifuged to separate the solid catalyst particles from the liquid, and the supernatant liquid was analysed using a Lambda UV-Vis spectrometer Model 750s (PerkinElmer, Shelton, CT, USA) at the wavelength of $284 \mathrm{~nm}$.

\subsection{Reusability Studies}

Reusability of the materials was studied using the dehydration of fructose into 5-HMF in DMSO as an illustrative reaction. The $\mathrm{C} \_\mathrm{S}$ and $\mathrm{TiO}_{2} \mathrm{C} \_\mathrm{S}$ composite acid catalysts were allowed to react for $1 \mathrm{~h}$ in separate vessels and then were separated from the solution by centrifugation. The recovered 
catalysts were then washed thoroughly with DI water and ethanol and dried for $4 \mathrm{~h}$ at $90{ }^{\circ} \mathrm{C}$. This process was repeated four times, with the 5-HMF yield calculated each time.

\subsection{Hot Filtration Tests}

The $1 \% \mathrm{TiO}_{2} \mathrm{C} \_\mathrm{S}, 5 \% \mathrm{TiO}_{2} \mathrm{C} \_\mathrm{S}$, and $10 \% \mathrm{TiO}_{2} \mathrm{C} \_\mathrm{S}$ acid catalysts were used to perform hot filtration tests to determine the heterogeneous nature of the acid catalyst. In a typical procedure, $0.5 \mathrm{~g}$ of fructose and $0.1 \mathrm{~g}$ of $\mathrm{TiO}_{2} \mathrm{C} \_\mathrm{S}$ were added to $6 \mathrm{ml}$ of DMSO and allowed to react for $30 \mathrm{~min}$ using the ultraclave high-performance microwave reactor. After the reaction, the solution was allowed to cool down and then was centrifuged to separate the catalyst from the reaction mixture. The solution was analysed using a UV-Vis spectrometer at a wavelength of $284 \mathrm{~nm}$. The same reaction was repeated for $1 \mathrm{~h}$ using the solution filtrate without adding the substrate.

\section{Results and Discussion}

\subsection{BET Surface Area and Pore Volume of the Catalysts}

The BET surface area and pore volume of the carbon spheres and the various compositions of the $\mathrm{TiO}_{2} \mathrm{C}$ composites are presented in Table 1 . The carbon spheres had a surface area of $517 \mathrm{~m}^{2} / \mathrm{g}$ before sulfonation. However, a reduction in surface area was observed after adding $\mathrm{TiO}_{2} \mathrm{NPs}$ to the carbon due to $\mathrm{TiO}_{2} \mathrm{NPs}$ blocking some of the micropores of the carbon. The $\mathrm{TiO}_{2} \mathrm{C}$ composite loaded with the lowest dosage of $\mathrm{TiO}_{2} \mathrm{NPs}$ (i.e., $1 \% \mathrm{TiO}_{2} \mathrm{C}$ ) had a larger surface area and pore volume of $413 \mathrm{~m}^{2} / \mathrm{g}$ and $0.26 \mathrm{~cm}^{3} / \mathrm{g}$, respectively, than the composites loaded with higher amounts of $\mathrm{TiO}_{2}$ (i.e., $5 \% \mathrm{TiO}_{2} \mathrm{C}$ and $10 \% \mathrm{TiO}_{2} \mathrm{C}$ ). The surface area of the $\mathrm{TiO}_{2} \mathrm{C}$ composite decreased when a high loading of $\mathrm{TiO}_{2} \mathrm{NPs}_{\mathrm{s}}$ was introduced onto the carbonaceous support. The $1 \% \mathrm{TiO}_{2} \mathrm{C}$ composite had the highest pore volume of $0.26 \mathrm{~cm}^{3} / \mathrm{g}$ compared to that of $5 \% \mathrm{TiO}_{2} \mathrm{C}$ and $10 \% \mathrm{TiO}_{2} \mathrm{C}$ composites. Both the surface area and the pore volume were affected by functionalising the carbon spheres and $\mathrm{TiO}_{2} \mathrm{C}$ with concentrated sulfuric acid. After sulfonation, the surface area of the carbon spheres decreased from 517 to $167 \mathrm{~m}^{2} / \mathrm{g}$ and that of the $1 \% \mathrm{TiO}_{2} \mathrm{C}, 5 \% \mathrm{TiO}_{2} \mathrm{C}$, and $10 \% \mathrm{TiO}_{2} \mathrm{C}$ composites decreased from 413 to 83,273 to 61 , and 202 to $59 \mathrm{~m}^{2} / \mathrm{g}$, respectively. Pore volume also decreased. The reduction in surface area and pore volume might be attributed to the $\mathrm{SO}_{3} \mathrm{H}$ groups that were attached to the pores of the carbon spheres and $\mathrm{TiO}_{2} \mathrm{C}$ composites during sulfonation. Other researchers reported similar results [21,22]. For example, Tamborini et al. [21] synthesised sulfonated porous carbon materials and used them for the production of biodiesel. The surface areas of the different synthesised carbons (PC100S and PC200S) were 630 and $695 \mathrm{~m}^{2} / \mathrm{g}$, respectively. The sulfonation process decreased the surface area of PC100S to $470 \mathrm{~m}^{2} / \mathrm{g}$ and that of PC200S to $140 \mathrm{~m}^{2} / \mathrm{g}$. The pore volume of the carbon materials also decreased from 0.92 to $0.77 \mathrm{~cm}^{3} / \mathrm{g}$ and from 1 to $0.34 \mathrm{~cm}^{3} / \mathrm{g}$, respectively. Sulfonation corroded the microporosity and mesoporosity of these carbon materials. Liu et al. [22] prepared a carbon-based acid catalyst and used it for the esterification of acetic acid with ethanol. After sulfonation, the surface area and pore volume of the activated carbon decreased from 751 to $602 \mathrm{~m}^{2} / \mathrm{g}$ and from 0.47 to $0.38 \mathrm{~cm}^{3} / \mathrm{g}$, respectively. Their findings suggested that $\mathrm{SO}_{3} \mathrm{H}$ groups were grafted onto the pore spaces of the activated carbons.

Table 1. Textural properties and hot filtration results of carbon spheres and $\mathrm{TiO}_{2} \mathrm{C}$ nanocomposites.

\begin{tabular}{|c|c|c|c|c|c|c|}
\hline \multicolumn{3}{|c|}{ Catalyst before Sulfonation } & \multicolumn{4}{|c|}{ Catalyst after Sulfonation } \\
\hline & $\begin{array}{c}S_{B E T} \\
\left(\mathrm{~m}^{2} / g\right)\end{array}$ & $\begin{array}{c}V_{p} \\
\left(\mathrm{~cm}^{3} / g\right)\end{array}$ & & $\begin{array}{c}S_{B E T} \\
\left(\mathrm{~m}^{2} / g\right)\end{array}$ & $\frac{V_{p}}{\left(\mathrm{~cm}^{3} / g\right)}$ & $\begin{array}{l}\text { Sulfonic Groups } \\
\left(\mathrm{m} \cdot \mathrm{molg}^{-1}\right)^{\mathrm{a}}\end{array}$ \\
\hline C & 517 & - & C_S & 167 & - & 1.34 \\
\hline $1 \% \mathrm{TiO}_{2} \mathrm{C}$ & 413 & 0.26 & $1 \% \mathrm{TiO}_{2} \mathrm{C} \_\mathrm{S}$ & 83 & 0.07 & 1.46 \\
\hline $5 \% \mathrm{TiO}_{2} \mathrm{C}$ & 273 & 0.13 & $5 \% \mathrm{TiO}_{2} \mathrm{C} \_\mathrm{S}$ & 61 & 0.04 & 1.55 \\
\hline $10 \% \mathrm{TiO}_{2} \mathrm{C}$ & 202 & 0.10 & $10 \% \mathrm{TiO}_{2} \mathrm{C} \_\mathrm{S}$ & 59 & 0.03 & 1.49 \\
\hline
\end{tabular}

C: Carbon; $\mathrm{S}_{\mathrm{BET}}$ : Surface Area; $\mathrm{V}_{\mathrm{p}}$ : Pore Volume; $\mathrm{S}_{-}$: Sulfonated; ${ }^{\mathrm{a}}$ Attained by titration with $\mathrm{NaOH}$. 
The acid strength of $\mathrm{C} \_\mathrm{S}, 1 \% \mathrm{TiO}_{2} \mathrm{C} \_\mathrm{S}, 5 \% \mathrm{TiO}_{2} \mathrm{C} \_\mathrm{S}$, and $10 \% \mathrm{TiO}_{2} \mathrm{C} \_\mathrm{S}$ was calculated to be 1.46 , $1.55,1.49$, and $1.36 \mathrm{mmol} \mathrm{g}^{-1}$, respectively, as seen in Table 1. The acid distribution results confirmed that $\mathrm{SO}_{3} \mathrm{H}$ acid sites were introduced onto the surface of the prepared catalysts, verifying the strong adsorption bands of the $\mathrm{S}=\mathrm{O}$ group at 1180 and $1008 \mathrm{~cm}^{-1}$, which were associated with the $\mathrm{SO}_{3}{ }^{-}$ groups in the FTIR spectra discussed in Section 3.3.

The heterogeneous nature of the $1 \% \mathrm{TiO}_{2} \mathrm{C} \_\mathrm{S}, 5 \% \mathrm{TiO}_{2} \mathrm{C} \_\mathrm{S}$, and $10 \% \mathrm{TiO}_{2} \mathrm{C} \_\mathrm{S}$ acid catalysts was evaluated using hot filtration tests conducted at optimum conditions. The results showed that leaching of $\mathrm{SO}_{3} \mathrm{H}$ functional groups did not occur during the dehydration of fructose to 5-HMF. The 5-HMF dehydration was about $80 \%$ after $30 \mathrm{~min}$ of reaction. The reaction was repeated again for $1 \mathrm{~h}$ and showed that the HMF dehydration did not improve beyond $80 \%$. These findings confirmed that the $\mathrm{TiO}_{2} \mathrm{C} \_\mathrm{S}$ acid catalysts are heterogeneous and that the functional groups were strongly attached to the surface of the $\mathrm{TiO}_{2} \mathrm{C} \_\mathrm{S}$ catalysts, so leaching did not occur.

\subsection{Surface Morphology}

The SEM images of the neat carbon and neat $\mathrm{TiO}_{2} \mathrm{C}$ composites are shown in Figure 1a-d, and those of the C_S and $\mathrm{TiO}_{2} \mathrm{C} \_\mathrm{S}$ acid catalysts are shown in Figure 1e-h. The neat carbon was spherical and had a smooth surface, with the spheres agglomerated and interconnected (Figure 1a). The neat $1 \% \mathrm{TiO}_{2} \mathrm{C} \_\mathrm{S}, 5 \% \mathrm{TiO}_{2} \mathrm{C} \_\mathrm{S}$, and $10 \% \mathrm{TiO}_{2} \mathrm{C} \_\mathrm{S}$ composites consisted of a combination of interconnected spheres and small $\mathrm{TiO}_{2}$ particles which did not have a definite shape, and were aggregated (Figure $1 \mathrm{~b}-\mathrm{d}$ ). Moreover, a high amount (5 and $10 \mathrm{wt} . \%$ ) of $\mathrm{TiO}_{2} \mathrm{NPs}$ loading promoted the formation of irregular $\mathrm{TiO}_{2}$ particles in the $\mathrm{TiO}_{2} \mathrm{C}$ composites. After sulfonation, the particles were found to have shrunk, as seen in Figure 1f-h, whereas in a case of $\mathrm{C} \_\mathrm{S}$ the spheres were found to have enlarged as shown in Figure 2e.
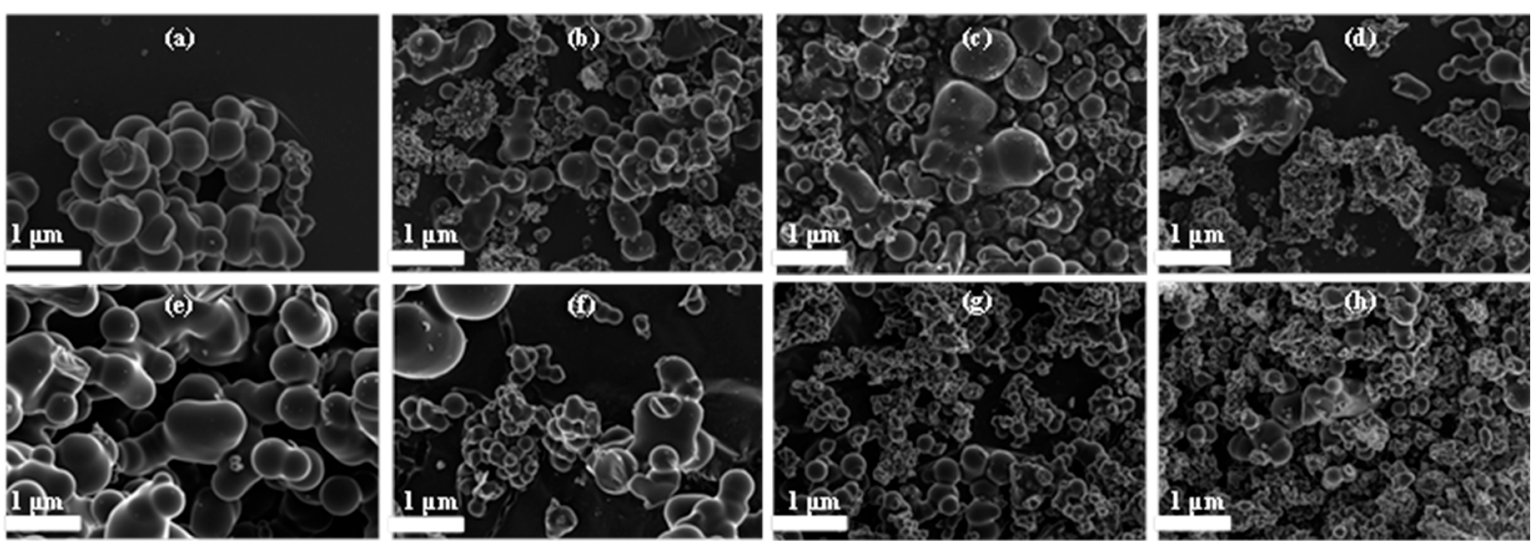

Figure 1. SEM low magnification images of (a) neat $\mathrm{C},(\mathbf{b})$ neat $1 \% \mathrm{TiO}_{2} \mathrm{C}$, (c) neat $5 \% \mathrm{TiO}_{2} \mathrm{C}$, (d) neat $10 \% \mathrm{TiO}_{2} \mathrm{C}$, (e) C_S solid acid catalyst, (f) $1 \% \mathrm{TiO}_{2} \mathrm{C} \_\mathrm{S}$ solid acid catalyst, (g) $5 \% \mathrm{TiO}_{2} \mathrm{C} \_\mathrm{S}$ solid acid catalyst, and (h) $10 \% \mathrm{TiO}_{2} \mathrm{C} \_$S solid acid catalyst.

Figure 2 shows the high magnification SEM images of (a) C_S solid acid catalyst, (b) 1\% $\mathrm{TiO}_{2} \mathrm{C} \_\mathrm{S}$, (c) $5 \% \mathrm{TiO}_{2} \mathrm{C} \_\mathrm{S}$, (d) $10 \% \mathrm{TiO}_{2} \mathrm{C} \_\mathrm{S}$ and (e) sulfonated $\mathrm{TiO}_{2}$. From Figure $2 \mathrm{a}$, we can see that the $\mathrm{C}_{-} \mathrm{S}$ solid acid catalyst had a smooth surface, whereas the $1 \% \mathrm{TiO}_{2} \mathrm{C} \_\mathrm{S}$ and $5 \% \mathrm{TiO}_{2} \mathrm{~S}$ showed the presence of small traces of $\mathrm{TiO}_{2}$ particles which were deposited onto the carbon surface. In the $10 \% \mathrm{TiO}_{2} \mathrm{C} \_\mathrm{S}$ sample (Figure 2d) $\mathrm{TiO}_{2}$ particles were deposited on the surface of the carbon. However, these $\mathrm{TiO}_{2}$ particles were not homogeneously distributed onto the surface of the carbon. In the sulfonated $\mathrm{TiO}_{2}$ sample (Figure 2e); SEM revealed that $\mathrm{TiO}_{2}$ particles had irregular shaped and were agglomerated. 

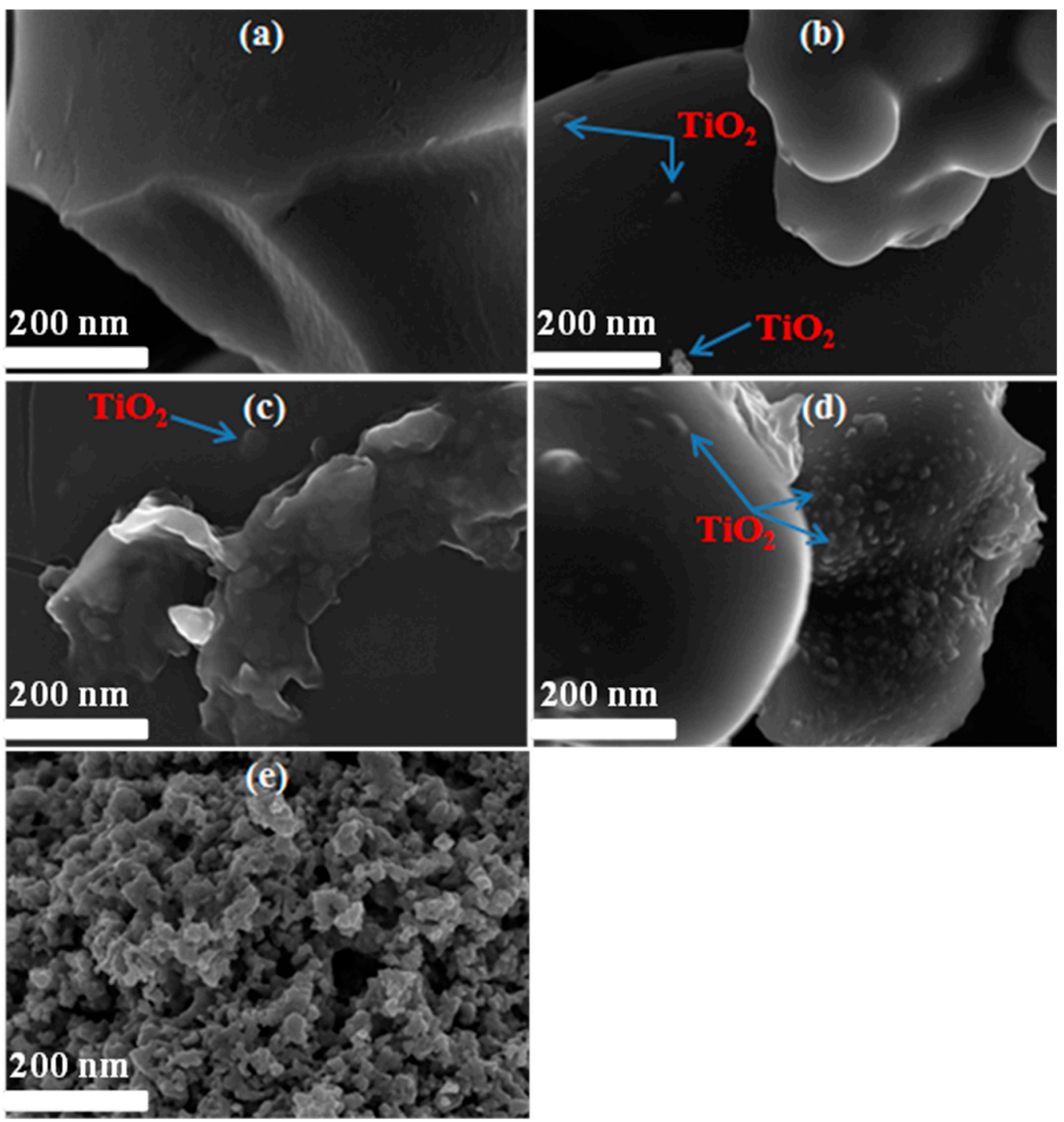

Figure 2. SEM high magnification images of (a) C_S solid acid catalyst, (b) $1 \% \mathrm{TiO}_{2} \mathrm{C} \_\mathrm{S}$ solid acid catalyst, (c) $5 \% \mathrm{TiO}_{2} \mathrm{C} \_\mathrm{S}$ solid acid catalyst, (d) $10 \% \mathrm{TiO}_{2} \mathrm{C} \_\mathrm{S}$ solid acid catalyst and (e) sulfonated $\mathrm{TiO}_{2}$.

The energy-dispersive spectroscopy (EDS) spectra of the neat carbon and neat $\mathrm{TiO}_{2} \mathrm{C}$ composites are shown in parts (a) to (d) of Figure 3, and those of the carbon spheres and $\mathrm{TiO}_{2} \mathrm{C}$ after sulfonation are shown in parts (e) to (h) of Figure 3. The EDS spectrum of the carbon spheres contains only $\mathrm{C}$ and $\mathrm{O}$ peaks, whereas that of the composite samples contains the Ti peak, confirming that $\mathrm{TiO}_{2}$ was present in the samples. The elemental weight percent of $\mathrm{C}$ decreased with an increase in $\mathrm{TiO}_{2}$ loading. After sulfonating the carbon, the $\mathrm{C}, \mathrm{O}$, and $\mathrm{S}$ peaks are present in the spectrum (Figure 3e), indicating that the carbon spheres were neat and no impurities were detected in the sample. The spectra of the $\mathrm{TiO}_{2} \mathrm{C} \_\mathrm{S}$ acid catalysts [parts (f) to (h) of Figure 3] showed the presence of $\mathrm{C}, \mathrm{O}, \mathrm{Ti}$, and $\mathrm{S}$, and the elemental weight percentage of Ti increased with an increase in the loading percentage of $\mathrm{TiO}_{2}$. However, the weight percentage of $\mathrm{C}$ decreased with an increase in the loading percentage of $\mathrm{TiO}_{2}$. No other impurity elements were found in the prepared solid acid catalysts. The presence of $S$ in all the solid acid catalysts indicated that the samples were successfully functionalised with sulfuric acid. Elemental composition analysis revealed that all the prepared acid catalysts contained sulfonic acid in the form of $\mathrm{SO}_{3} \mathrm{H}$ groups [23], further proving the presence of sulfonic groups, as indicated in Table 1 . Wang et al. [14] also confirmed the presence of sulfonic groups on the surface of carbon materials after sulfonation. The $\mathrm{TiO}_{2} \mathrm{C} \_\mathrm{S}$ composites had $\mathrm{C}, \mathrm{O}, \mathrm{Ti}$, and $\mathrm{S}$, and their elemental weight percent of $\mathrm{Ti}$ 
increased with an increase in the loading percentage of Ti. However, the weight percent of $C$ decreased with an increase in the loading percentage of Ti.
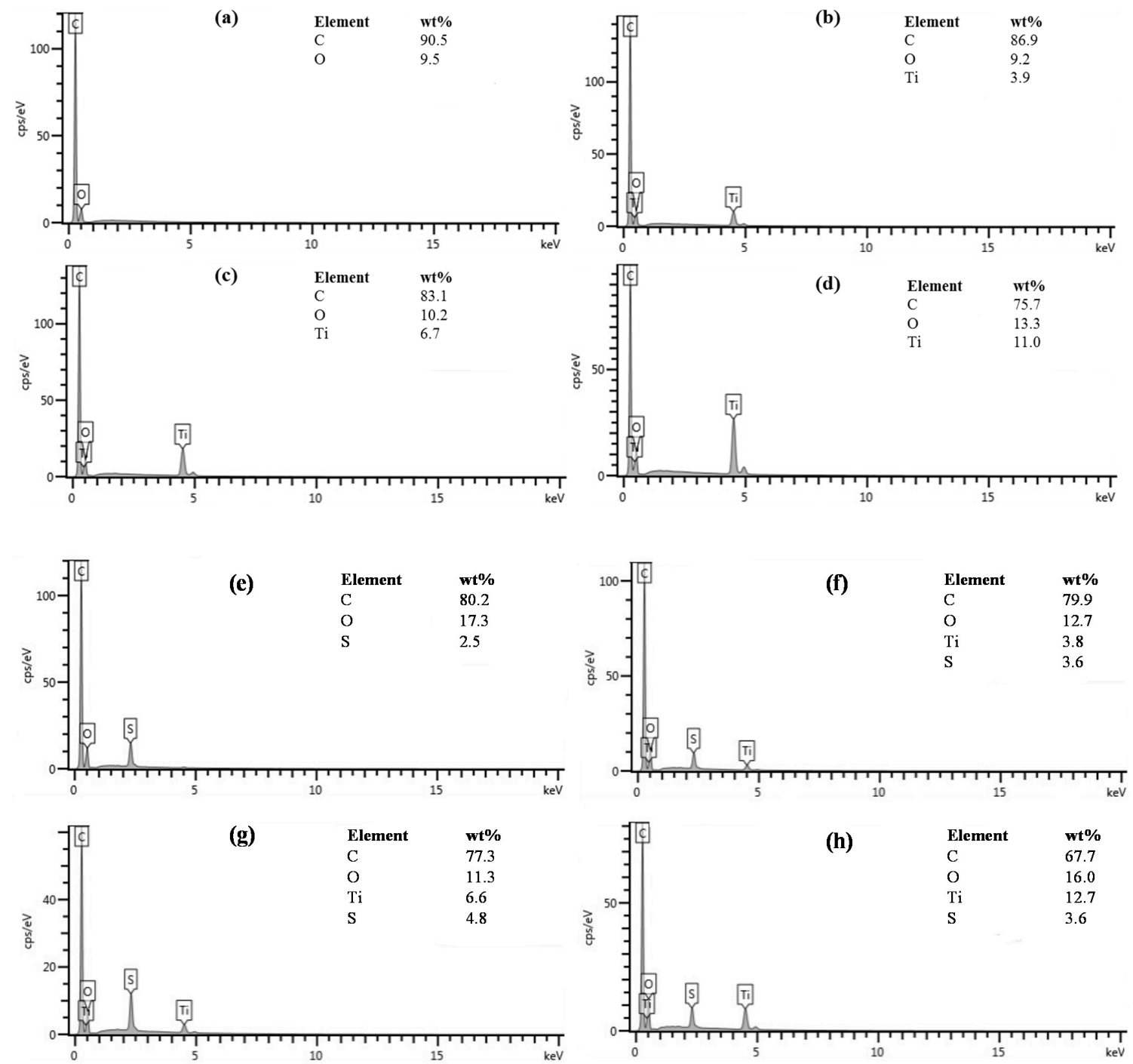

Figure 3. EDS spectra and elemental composition of (a) neat $\mathrm{C}$, (b) neat $1 \% \mathrm{TiO}_{2} \mathrm{C}$, (c) neat $5 \% \mathrm{TiO}_{2} \mathrm{C}$, (d) neat $10 \% \mathrm{TiO}_{2} \mathrm{C}$, (e) C_S solid acid catalyst, (f) $1 \% \mathrm{TiO}_{2} \mathrm{C} \_\mathrm{S}$ solid acid catalyst, (g) $5 \% \mathrm{TiO}_{2} \mathrm{C} \_\mathrm{S}$ solid acid catalyst, and (h) $10 \% \mathrm{TiO}_{2} \mathrm{C} \_$S solid acid catalyst.

\subsection{Chemical Analysis Using FTIR}

The FTIR spectra of the neat, calcined, and sulfonated carbon spheres are shown in Figure 4a. The presence of oxygen groups is demonstrated by the bands at 3000-3600 and $1710 \mathrm{~cm}^{-1}$, which were attributed to $-\mathrm{OH}$ stretching and $\mathrm{C}=\mathrm{O}$ vibrations, respectively $[3,24]$. The $875-750 \mathrm{~cm}^{-1}$ band was assigned to the aromatic $\mathrm{C}-\mathrm{H}$ group, and the presence of aromatic rings was confirmed by the band at $1620 \mathrm{~cm}^{-1}$, which was assigned to $\mathrm{C}=\mathrm{C}$ vibrations [24]. Additional bands at 1180 and 1008 and $1106-1168 \mathrm{~cm}^{-1}$ were observed in the spectrum of the sulfonated carbon spheres. These bands were assigned to the symmetric stretching vibration of $\mathrm{S}=\mathrm{O}$ groups, which are associated with the $\mathrm{SO}_{3}{ }^{-}$ groups [25] and $C=S$ stretching [26], respectively as shown in Figure 4a. These sulfonic peaks in the spectrum of the sulfonated carbon spheres indicate that $-\mathrm{SO}_{3} \mathrm{H}$ functional groups were attached to the carbon spheres. The FTIR spectra of the neat, calcined, and sulfonated $1 \% \mathrm{TiO}_{2} \mathrm{C}, 5 \% \mathrm{TiO}_{2} \mathrm{C}$, and $10 \% \mathrm{TiO}_{2} \mathrm{C}$ (Figure $4 \mathrm{~b}-\mathrm{d}$ ) show bands at 1700 and $1200 \mathrm{~cm}^{-1}$, which were attributed to the $\mathrm{C}=\mathrm{O}$ and 
C-O stretching of the carboxyl group [27]. A strong adsorption band of the $\mathrm{S}=\mathrm{O}$ group at $1008 \mathrm{~cm}^{-1}$, which was associated with the $\mathrm{SO}_{3}{ }^{-}$groups, was observed.
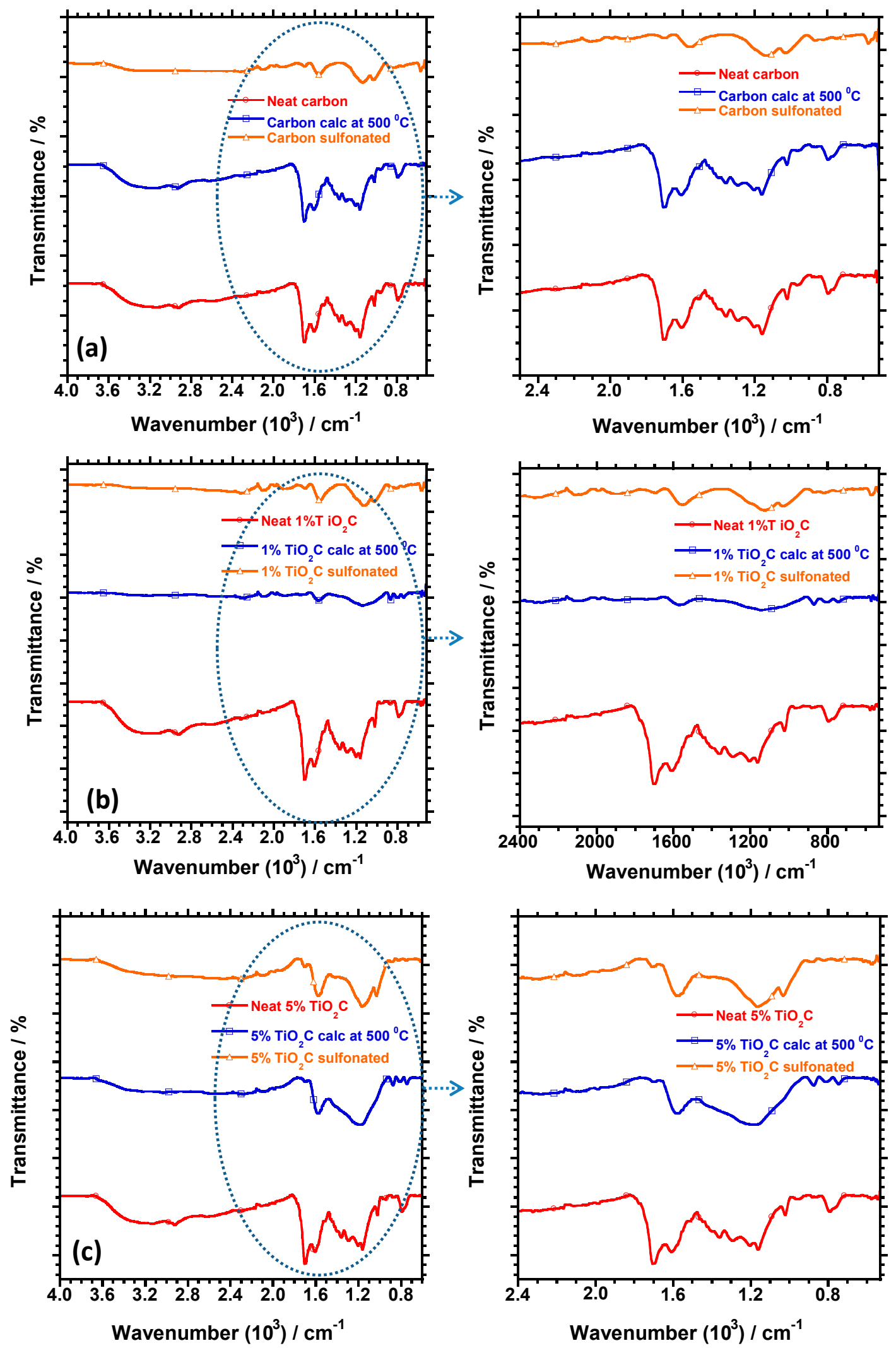

Figure 4. Cont. 

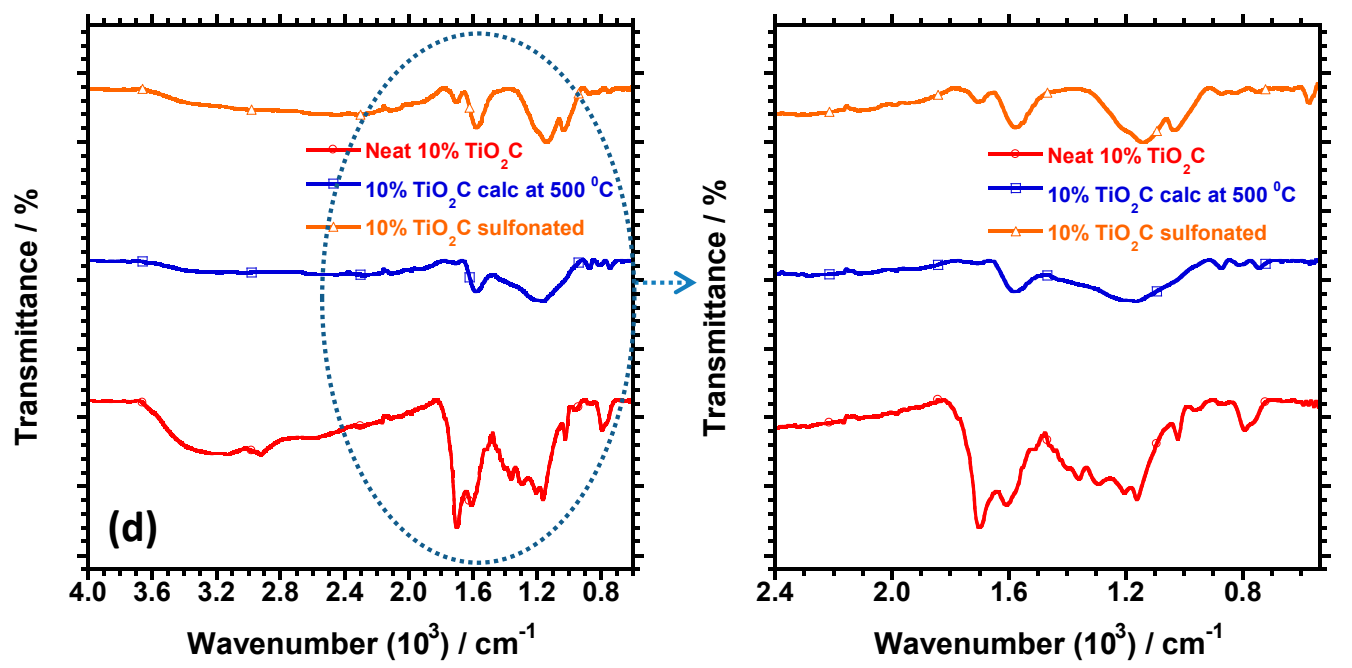

Figure 4. FTIR spectra of neat, calcined and sulfonated (a) carbon, (b) $1 \% \mathrm{TiO}_{2} \mathrm{C}$, (c) $5 \% \mathrm{TiO}_{2} \mathrm{C}$, and (d) $10 \% \mathrm{TiO}_{2} \mathrm{C}$.

\subsection{Structural Characterisation Using XRD}

The XRD patterns of the calcined carbon spheres and $\mathrm{TiO}_{2} \mathrm{C}$ composites are shown in Figure $5 \mathrm{a}$. The XRD pattern of the neat carbon spheres showed broad peaks at $25^{\circ}$ and $43^{\circ}$, which were indexed to the [002] and [100] characteristic phases of amorphous carbonaceous material, whereas the $\mathrm{TiO}_{2} \mathrm{C}$ sample which was loaded with the least dosage of $\mathrm{TiO}_{2}\left(1 \% \mathrm{TiO}_{2} \mathrm{C}\right)$, was found to be amorphous, due to the effect of high concentration of the carbon which was present in the sample. The XRD pattern of the crystalline structure of the $5 \% \mathrm{TiO}_{2} \mathrm{C}$ and $10 \% \mathrm{TiO}_{2} \mathrm{C}$ composites had sharp peaks at $25.2^{\circ}, 37.83^{\circ}, 48.2^{\circ}$, $54.8^{\circ}, 62.2^{\circ}$, and $70.2^{\circ}$, which were indexed to the [101], [004], [200], [105], [204], and [116] phases of anatase $\mathrm{TiO}_{2}$ [28]. After sulfonation, the peaks for the carbon spheres and $1 \% \mathrm{TiO}_{2} \mathrm{C}$ shifted, as shown in Figure 5b. Moreover, the acid treatment (sulfonation) caused the [100] plane peak to disappear. The $5 \% \mathrm{TiO}_{2} \mathrm{C}$ and $10 \% \mathrm{TiO}_{2} \mathrm{C}$ composites were not affected by the sulfonation.
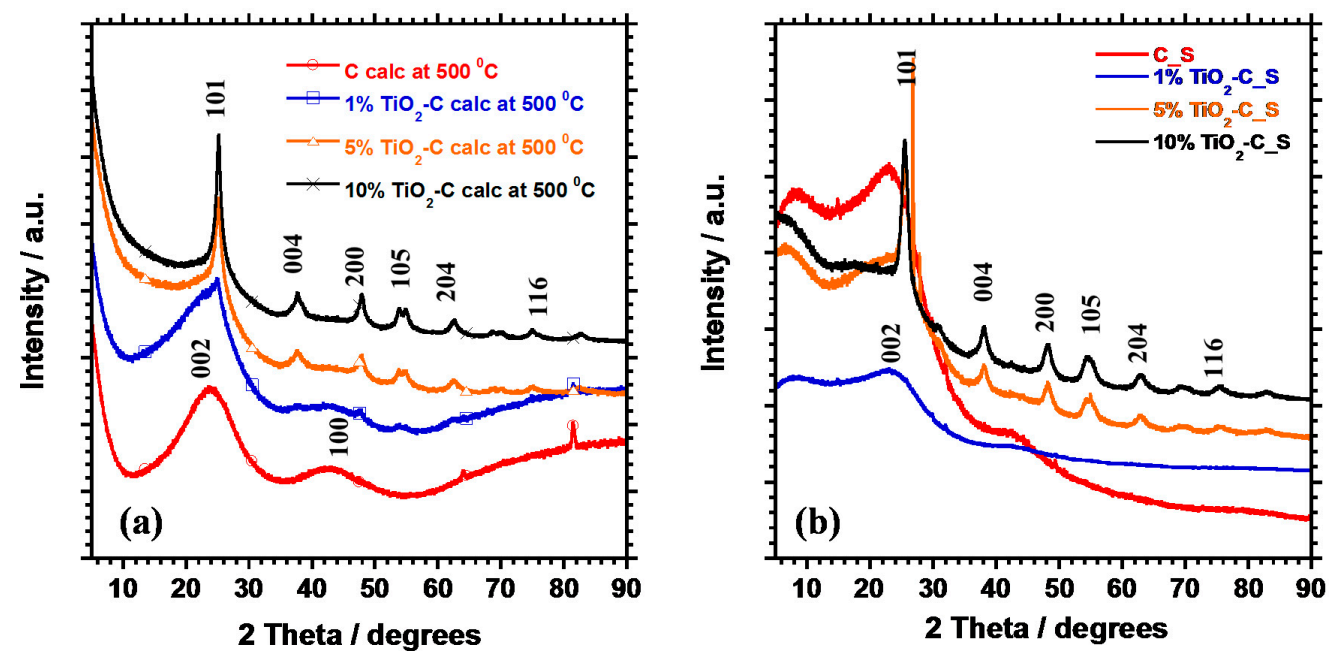

Figure 5. XRD results for carbon spheres and $\mathrm{TiO}_{2} \mathrm{C}$ composites (a) that were calcined at $500{ }^{\circ} \mathrm{C}$ and (b) after sulfonation.

\subsection{Catalytic Testing}

\subsubsection{Effect of Different Solvents on the Dehydration of Fructose into 5-HMF}

Dehydration of fructose into 5-HMF was tested using different alcoholic solvents (such as isopropanol, ethanol, and methanol), water, and DMSO at $120^{\circ} \mathrm{C}$ for $60 \mathrm{~min}$ (Table 2). All the 
alcoholic solvents produced a low 5-HMF yield of $<12 \%$ on all the solid catalysts tested for this reaction. Water was also found to be an ineffective solvent. DMSO was the most effective solvent. The HMF yield was $84 \%$ for the carbon solid acid catalyst, $91 \%$ for $1 \% \mathrm{TiO}_{2} \mathrm{C} \_\mathrm{S}, 92 \%$ for $5 \% \mathrm{TiO}_{2} \mathrm{C} \_\mathrm{S}$, and $95 \%$ for $10 \% \mathrm{TiO}_{2} \mathrm{C} \_$S. Thus, the HMF dehydration increased as the $\mathrm{TiO}_{2}$ content increased. These results suggest that DMSO is a suitable solvent for use in the dehydration of fructose into 5-HMF when using $\mathrm{TiO}_{2} \mathrm{C}$ solid acid catalysts. DMSO acted both as a solvent and as a reaction mediator; hence a high dehydration of 5-HMF was achieved.

Table 2. Dehydration of fructose in different solvents.

\begin{tabular}{cccccc}
\hline \multirow{2}{*}{ Catalyst } & \multicolumn{5}{c}{ HMF Dehydration (\%) } \\
& Methanol & DI Water & Ethanol & Isopropanol & DMSO \\
\hline $\mathrm{C}$ & 3 & 5 & 11 & 1 & 84 \\
$1 \% \mathrm{TiO}_{2} \mathrm{C}$ & 3 & 6 & 4 & 9 & 91 \\
$5 \% \mathrm{TiO}_{2} \mathrm{C}$ & 3 & 1 & 6 & 0 & 92 \\
$10 \% \mathrm{TiO}_{2} \mathrm{C}$ & 0 & 4 & 12 & 11 & 95 \\
\hline Reaction conditions: Substrate, fructose; catalyst amount, $0.1 \mathrm{~g}$; temperature, $120^{\circ} \mathrm{C}$; time, $60 \mathrm{~min}$.
\end{tabular}

Table 3 shows a comparison of the $\mathrm{TiO}_{2} \mathrm{C}$ composite acid catalyst synthesised in this work with other catalysts reported in published works on dehydration of fructose into 5-HMF in DMSO using the microwave-assisted method. We found that our designed $\mathrm{TiO}_{2} \mathrm{C} \_\mathrm{S}$ acid catalysts produced the highest 5-HMF yield. The highest 5-HMF yield that we achieved at $120{ }^{\circ} \mathrm{C}$, a temperature lower than those used in other studies, was $91 \%$ for $1 \% \mathrm{TiO}_{2} \mathrm{C} \_\mathrm{S}$ and 92 and $95 \%$ for $5 \% \mathrm{TiO}_{2} \mathrm{C} \_\mathrm{S}$ and $10 \% \mathrm{TiO}_{2} \mathrm{C} \_\mathrm{S}$, respectively. To our knowledge, this is the first report of the use of $\mathrm{TiO}_{2} \mathrm{C} \_\mathrm{S}$ composites as effective solid acid catalysts for the conversion of fructose into 5-HMF using the microwave-assisted method. De et al. [19] used mesoporous $\mathrm{TiO}_{2}$ nanomaterial to catalyse the dehydration of D-fructose into 5-HMF in DMSO solvent under microwave-assisted heating. This reaction was conducted at $130^{\circ} \mathrm{C}$ for $2 \mathrm{~min}$ for a 49.2\% 5-HMF yield was achieved. Dutta et al. [15] also used mesoporous $\mathrm{TiO}_{2}$ nanoparticles for the same reaction at $140{ }^{\circ} \mathrm{C}$ for $5 \mathrm{~min}$ and reported a yield of $53.4 \%$. Use of carbonaceous acid catalysts for this reaction achieved a $100 \%$ conversion of fructose and $90 \% 5-\mathrm{HMF}$ yield at $160{ }^{\circ} \mathrm{C}$ for $1.5 \mathrm{~h}$. Wang et al. [16] used carbon-based solid acid catalysts to catalyse the dehydration of fructose into $5-\mathrm{HMF}$ at $130^{\circ} \mathrm{C}$ for $1.5 \mathrm{~h}$ for a 5-HMF yield of about $91.2 \%$. Hu et al. [18] explored a magnetic lignin-derived carbonaceous acid catalyst for the catalysed conversion of fructose into 5-HMF and achieved a $5-\mathrm{HMF}$ yield of $81.1 \%$ with $100 \%$ fructose conversion.

Table 3. Comparison of results of the dehydration of fructose (substrate) into 5-HMF in DMSO using carbonaceous and $\mathrm{TiO}_{2}$-based solid acid catalysts.

\begin{tabular}{|c|c|c|c|c|c|c|c|}
\hline \multirow{2}{*}{ Catalyst } & \multirow{2}{*}{$\begin{array}{l}\text { Catalyst Mass } \\
\text { (g) }\end{array}$} & \multirow{2}{*}{$\begin{array}{l}\text { Substrate Mass } \\
\text { (g) }\end{array}$} & \multirow{2}{*}{$\begin{array}{c}\mathrm{T} \\
\left({ }^{\circ} \mathrm{C}\right)\end{array}$} & \multirow{2}{*}{$\begin{array}{l}\text { Time } \\
(\mathrm{min})\end{array}$} & \multicolumn{2}{|c|}{ 5-HMF Yield (\%) } & \multirow{2}{*}{ Ref. } \\
\hline & & & & & Uv-Vis ${ }^{a}$ & HPLC $^{b}$ & \\
\hline C_S & 0.1 & 0.5 & 120 & 60 & 84 & - & This work \\
\hline $1 \% \mathrm{TiO}_{2} \mathrm{C} \_\mathrm{S}$ & 0.1 & 0.5 & 120 & 60 & 91 & - & This work \\
\hline $5 \% \mathrm{TiO}_{2} \mathrm{C}-\mathrm{S}$ & 0.1 & 0.5 & 120 & 60 & 92 & - & This work \\
\hline $10 \% \mathrm{TiO}_{2} \mathrm{C} \_\mathrm{S}$ & 0.1 & 0.5 & 120 & 60 & 95 & - & This work \\
\hline $\mathrm{TiO}_{2}$ & 0.05 & 0.1 & 130 & 2 & 49.5 & 47.8 & [19] \\
\hline $\mathrm{TiO}_{2}$ & 0.1 & 0.05 & 140 & 5 & 53.4 & - & [20] \\
\hline $\mathrm{CS}^{2}$ & 0.1 & 0.5 & 160 & 90 & - & 90 & [15] \\
\hline $\mathrm{C}$ & 0.4 & 0.5 & 130 & 90 & - & 91.2 & [16] \\
\hline $\begin{array}{l}\text { Magnetic lignin-derived } \\
\text { carbon (MLC)-SO } \mathrm{S}_{3} \mathrm{H}\end{array}$ & 0.05 & 0.1 & 130 & 40 & - & 81.1 & [18] \\
\hline
\end{tabular}

a 5 -HMF dehydration was calculated by UV-vis at the measured absorbance of $284 \mathrm{~nm}$; ${ }^{\text {b }} 5$-HMF dehydration measured by HPLC.

\subsubsection{Effect of Reaction Temperature on HMF Dehydration}

The effect of reaction temperature on the catalytic transformation of fructose to $\mathrm{HMF}$ was carried out at $25,60,80,100$ and $120^{\circ} \mathrm{C}$. The reaction was conducted using $1 \% \mathrm{TiO}_{2} \mathrm{C} \_\mathrm{S}, 5 \% \mathrm{TiO}_{2} \mathrm{C} \_\mathrm{S}$, 
$10 \% \mathrm{TiO}_{2} \mathrm{C} \_\mathrm{S}, \mathrm{C} \_\mathrm{S}$ solid acid catalysts and without the catalyst (non-catalytic reaction). The results are shown in Figure 6, which suggests that no 5-HMF was formed when the reaction was carried out in the absence of a catalyst on all the reaction temperatures that were studied. For the carbon solid acid catalyst and reaction temperature of $25{ }^{\circ} \mathrm{C}$, the $5-\mathrm{HMF}$ yield was $<8 \%$. When the temperature was raised to $60{ }^{\circ} \mathrm{C}$, the 5 -HMF yield slightly increased to $35 \%$. At $80{ }^{\circ} \mathrm{C}$, the 5 -HMF yield improved to $71 \%$. The highest $5-\mathrm{HMF}$ yield of $85 \%$ was achieved at $120{ }^{\circ} \mathrm{C}$. The effect of reaction temperature was also tested using the $1 \% \mathrm{TiO}_{2} \mathrm{C} \_\mathrm{S}, 5 \% \mathrm{TiO}_{2} \mathrm{C} \_\mathrm{S}$, and $10 \% \mathrm{TiO}_{2} \mathrm{C} \_\mathrm{S}$ solid acid catalysts. The 5-HMF yield was low when the reaction was conducted at $25^{\circ} \mathrm{C}$, then increased as the reaction temperature increased. The highest HMF yields of 91,92 , and $95 \%$ were achieved at $120{ }^{\circ} \mathrm{C}$ with the use of $1 \% \mathrm{TiO}_{2} \mathrm{C} \_$, $5 \% \mathrm{TiO}_{2} \mathrm{C} \_\mathrm{S}$, and $10 \% \mathrm{TiO}_{2} \mathrm{C} \_\mathrm{S}$ solid acid catalysts, respectively. Thus, the best temperature for 5-HMF production using these composite catalysts was $120^{\circ} \mathrm{C}$. Compared to the performance of the carbon solid acid catalyst, an improved HMF yield was achieved with the use of 1, 5, and $10 \% \mathrm{TiO}_{2} \mathrm{C} \_\mathrm{S}$ solid acid catalysts.

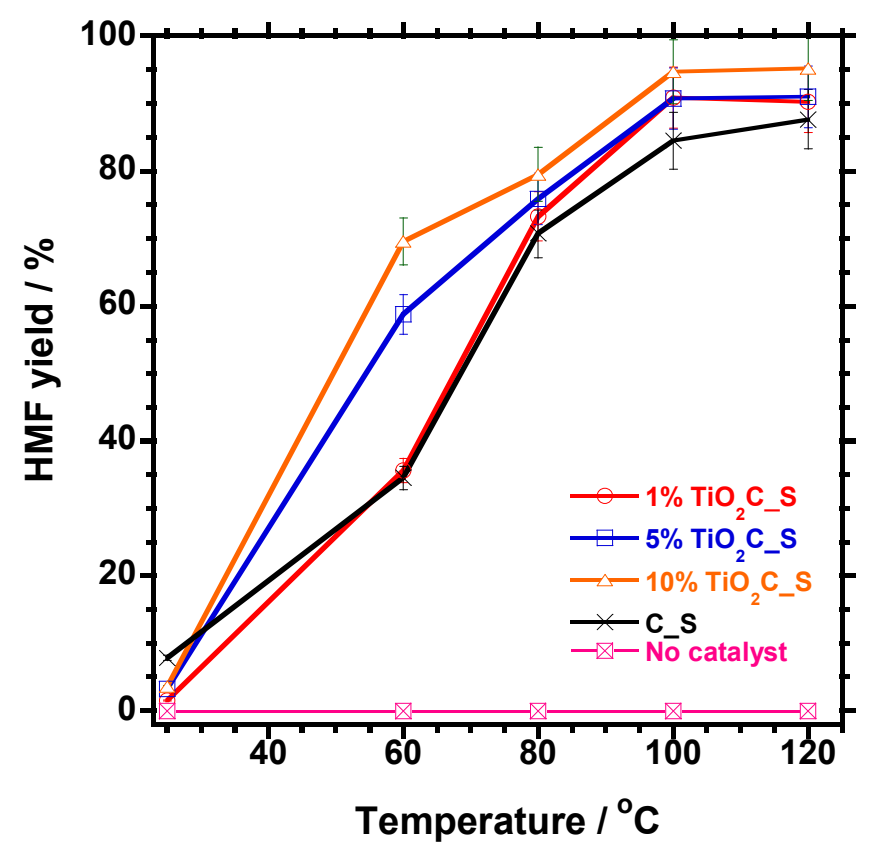

Figure 6. Effect of reaction temperature on fructose dehydration into HMF using sulfonated carbon and $\mathrm{TiO}_{2} \mathrm{C}$ composite catalysts in DMSO solvent.

\subsubsection{Effect of Reaction Time on 5-HMF Dehydration}

The effect of reaction time on the catalysed dehydration of fructose into 5-HMF was studied using different times of 15, 30, 60, and $120 \mathrm{~min}$. The reaction was conducted using the prepared solid acid catalysts and no catalyst (non-catalytic reaction). The results are shown in Figure 7. No 5-HMF was formed when the reaction was carried out without a catalyst for all four reaction times. When the reaction was performed with the C_S solid acid catalyst, increasing the reaction time from 15 to $30 \mathrm{~min}$ improved the 5-HMF yield from $25 \%$ to $46 \%$. The HMF dehydration increased rapidly to $85 \%$ after conducting the reaction for $60 \mathrm{~min}$. However, performing the reaction for $120 \mathrm{~min}$ caused a slight drop in the 5-HMF yield to $83 \%$. When conducting the dehydration reaction using $1 \% \mathrm{TiO}_{2} \mathrm{C} \_\mathrm{S}$, $5 \% \mathrm{TiO}_{2} \mathrm{C} \_$S , and $10 \% \mathrm{TiO}_{2} \mathrm{C} \_\mathrm{S}$ solid acid catalysts, increasing the reaction time from 15 to $30 \mathrm{~min}$ increased the 5-HMF yield from 27 to $49 \%, 28$ to $58 \%$, and 29 to $68 \%$, respectively. Increasing the reaction time to $60 \mathrm{~min}$ significantly improved the 5-HMF yield to $>90 \%$ for all the $\mathrm{TiO}_{2} \mathrm{C}$ composite acid catalysts. Finally, for a reaction time of $120 \mathrm{~min}$, the $\mathrm{HMF}$ dehydration for $1 \% \mathrm{TiO}_{2} \mathrm{C} \_\mathrm{S}, 5 \% \mathrm{TiO}_{2} \mathrm{C} \_\mathrm{S}$, and $10 \% \mathrm{TiO}_{2} \mathrm{C} \_\mathrm{S}$ solid acid catalysts was calculated to be 88,92 , and $93 \%$, respectively. 


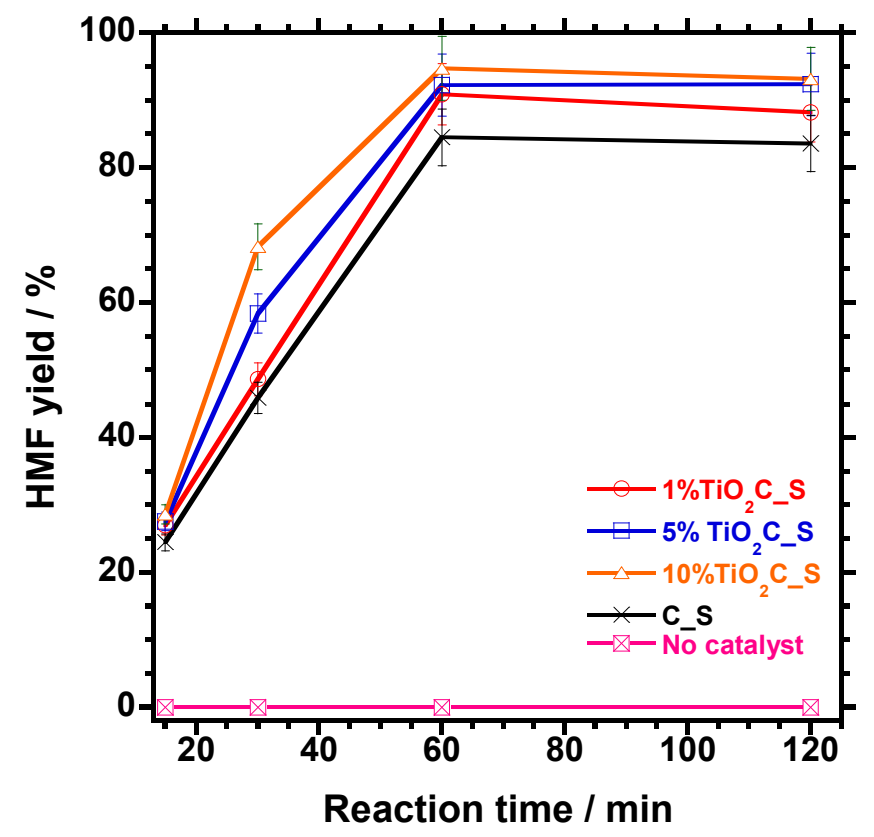

Figure 7. Effect of reaction time on the dehydration of fructose into HMF in DMSO solvent.

\subsubsection{Effect of Catalyst Amount on HMF Dehydration}

The effect of the amount of catalyst on the 5-HMF yield was studied, with the results presented in Figure 8 . The reaction was carried out using catalyst dosages of $0.02,0.05,0.1$, and $0.2 \mathrm{~g}$. The results indicated that no 5-HMF was formed when this reaction was conducted in the absence of a catalyst on all the catalyst dosages that were studied. The 5-HMF yield increased from 34 to $59 \%$ when the amount of the C_S solid acid catalyst increased from 0.02 to $0.05 \mathrm{~g}$ under the same reaction conditions. An increase in the catalyst dosage to $0.1 \mathrm{~g}$ increased the 5-HMF yield to $85 \%$. However, increasing the catalyst dosage to $0.2 \mathrm{~g}$ resulted in a reduction of the 5-HMF yield to $82 \%$. The effect of catalyst concentration was also tested using the $1 \% \mathrm{TiO}_{2} \mathrm{C} \_\mathrm{S}, 5 \% \mathrm{TiO}_{2} \mathrm{C} \_\mathrm{S}$, and $10 \% \mathrm{TiO}_{2} \mathrm{C} \_\mathrm{S}$ solid acid catalysts. An increase in the catalyst dosage from 0.02 to $0.1 \mathrm{~g}$ drastically improved the 5-HMF yield of the $1 \% \mathrm{TiO}_{2} \mathrm{C} \_\mathrm{S}, 5 \% \mathrm{TiO}_{2} \mathrm{C} \_\mathrm{S}$, and $10 \% \mathrm{TiO}_{2} \mathrm{C} \_\mathrm{S}$ solid acid catalysts to 91,92 , and $95 \%$, respectively. However, when the catalyst dosage increased to $0.2 \mathrm{~g}$, the 5 - $\mathrm{HMF}$ yield of the $5 \% \mathrm{TiO}_{2} \mathrm{C}_{-} \mathrm{S}$, and $10 \% \mathrm{TiO}_{2} \mathrm{C}_{-} \mathrm{S}$ solid acid catalysts slightly decreased to 91 and $92 \%$ respectively, whereas in a case of the $1 \% \mathrm{TiO}_{2} \mathrm{C} \_\mathrm{S}$ the $5-\mathrm{HMF}$ yield increased to $93 \%$. This decrease in 5-HMF dehydration at a high catalyst dosage for the $5 \% \mathrm{TiO}_{2} \mathrm{C} \_\mathrm{S}$ and $10 \% \mathrm{TiO}_{2} \mathrm{C} \_\mathrm{S}$, could be attributed to the excess acid active sites that promote both the dehydration reaction and the formation of by-products such as humins [29]. The 5-HMF yields did not increase with an increase in catalyst dosage for the C_S, 5\% $\mathrm{TiO}_{2} \mathrm{C} \_\mathrm{S}$ and $10 \% \mathrm{TiO}_{2} \mathrm{C} \_\mathrm{S}$ solid acid catalysts. 


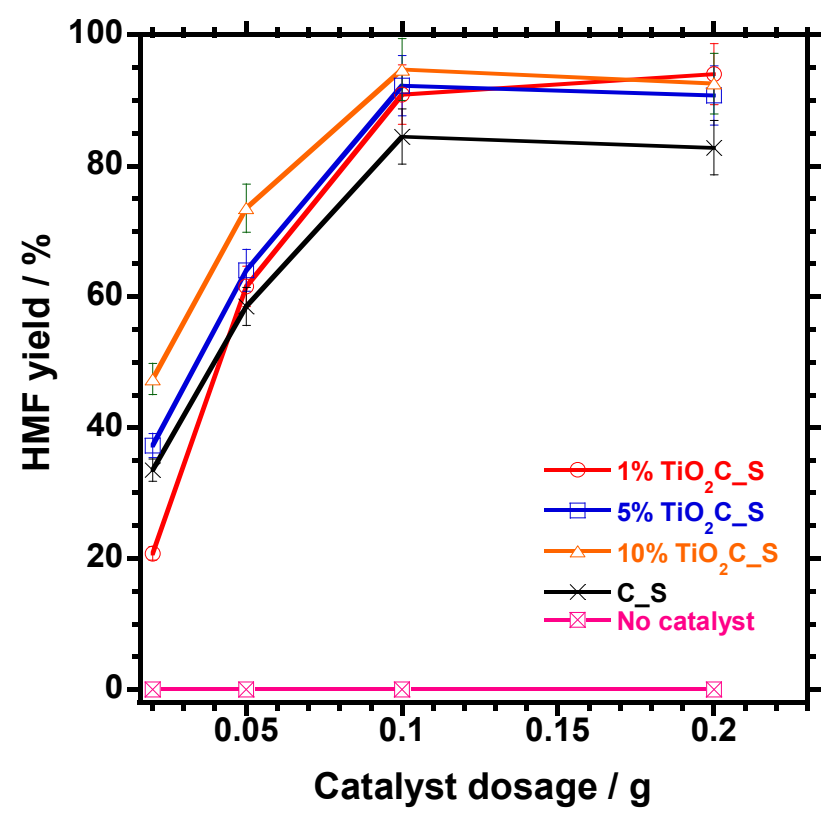

Figure 8. Effect of catalyst dosage on the dehydration of fructose into HMF in DMSO solvent.

\subsubsection{Reusability of the Catalyst}

The reusability of the catalysts was studied, with the results presented in Figure 9. After the first run, the 5-HMF yields were 94,97 , and $93 \%$ for $1 \% \mathrm{TiO}_{2} \mathrm{C} \_\mathrm{S}, 5 \% \mathrm{TiO}_{2} \mathrm{C} \_\mathrm{S}$, and $10 \% \mathrm{TiO}_{2} \mathrm{C} \_\mathrm{S}$, respectively. The 5-HMF yield slightly decreased after the fourth run. The 5-HMF yield of the $1 \% \mathrm{TiO}_{2} \mathrm{C} \_\mathrm{S}$ and $10 \% \mathrm{TiO}_{2} \mathrm{C} \_\mathrm{S}$ composite acid catalysts decreased by $3 \%$ and that of $5 \% \mathrm{TiO}_{2} \mathrm{C} \_\mathrm{S}$ decreased by $5 \%$. These results indicate that the $\mathrm{TiO}_{2} \mathrm{C}$ composite acid catalysts are highly stable and can be reused for the dehydration of fructose.

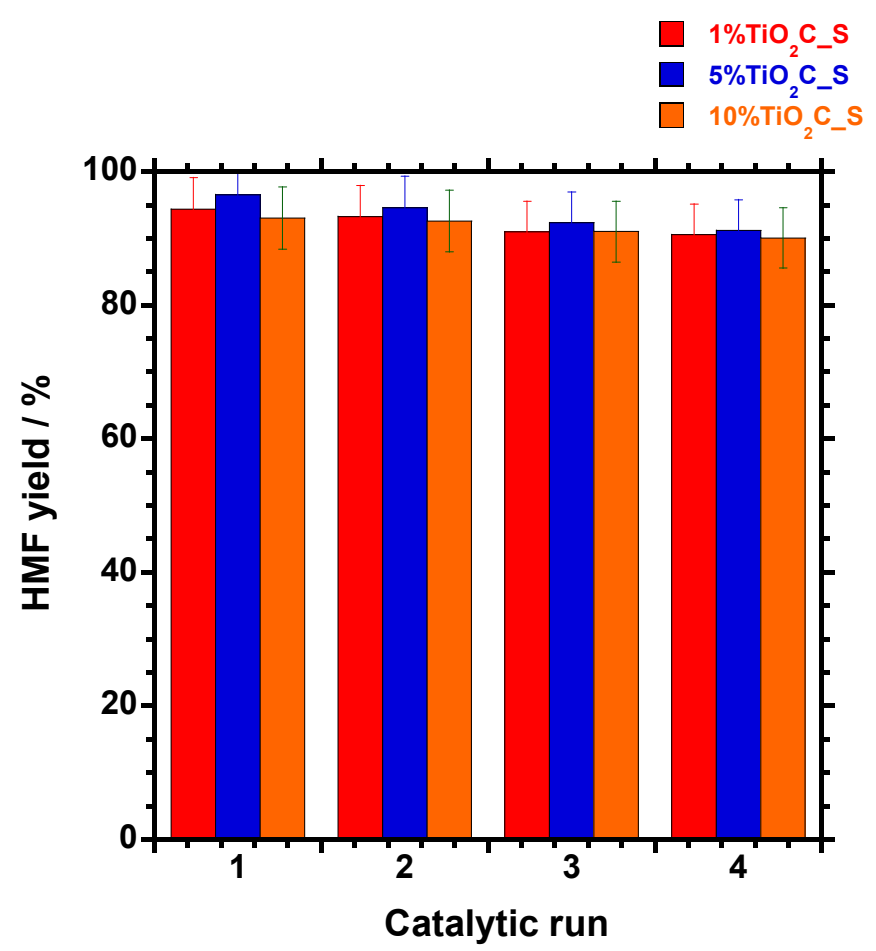

Figure 9. Recycling of the $1 \% \mathrm{TiO}_{2} \mathrm{C} \_\mathrm{S}, 5 \% \mathrm{TiO}_{2} \mathrm{C} \_\mathrm{S}$, and $10 \% \mathrm{TiO}_{2} \mathrm{C} \_\mathrm{S}$ acid catalysts used in the dehydration of fructose into HMF. Conditions: reaction time $=60 \mathrm{~min}$, reaction temperature $=120^{\circ} \mathrm{C}$, catalyst concentration $=0.1 \mathrm{~g}$, amount of fructose $=0.5 \mathrm{~g}$, volume of DMSO $=6 \mathrm{~mL}$ ). 


\section{Conclusions}

$\mathrm{TiO}_{2} \mathrm{C}$ solid acid catalysts were successfully prepared using the microwave-assisted method and then sulfonated with concentrated sulfuric acid. Microwave heating increases the rate of dehydration of fructose. The dehydration of fructose is closely related to the acidity of the catalyst. Among the solvents tested for use in the dehydration of fructose into 5-HMF, DMSO performed the best in terms of 5-HMF dehydration. The reaction temperature, reaction time, and catalyst dosage were found to have an effect on the 5-HMF dehydration. The solid acid catalysts synthesised in this work were highly stable and heterogeneous. Moreover, this study was the first time such $\mathrm{TiO}_{2} \mathrm{C}$ solid acid catalysts were used for dehydrating fructose into 5-HMF.

Author Contributions: M.M.S. design the concept and wrote the first draft of manuscript. R.M. went through manuscript and provided comments. S.S.R. critically reviewed and corrected the manuscript.

Funding: The authors are grateful to the Department of Science and Technology (DST, project no. HGERA8X) and the Council for Scientific and Industrial Research (CSIR, project no. HGER74p) of South Africa for financial support.

Conflicts of Interest: The authors declare no conflict of interest.

\section{References}

1. Démolis, A.; Essayem, N.; Rataboul, F. Synthesis and applications of alkyl levulinates. ACS Sustain. Chem. Eng. 2014, 2, 1338-1352. [CrossRef]

2. McNeff, C.V.; Nowlan, D.T.; McNeff, L.C.; Yan, B.; Fedie, R.L. Continuous production of 5-hydroxymethylfurfural from simple and complex carbohydrates. Appl. Catal. A Gen. 2010, 384, 65-69. [CrossRef]

3. Qi, X.; Watanabe, M.; Aida, T.M.; Smith, R.L., Jr. Catalytical conversion of fructose and glucose into 5-hydroxymethylfurfural in hot compressed water by microwave heating. Catal. Commun. 2008, 9, 2244-2249. [CrossRef]

4. Wang, J.; Ren, J.; Liu, X.; Xi, J.; Xia, Q.; Zu, Y.; Lu, G.; Wang, Y. Direct conversion of carbohydrates to 5-hydroxymethylfurfural using Sn-Mont catalyst. Green Chem. 2012, 14, 2506-2512. [CrossRef]

5. Moreau, C.; Finiels, A.; Vanoye, L. Dehydration of fructose and sucrose into 5 hydroxymethylfurfural in the presence of 1-H-3-methyl imidazolium chloride acting both as solvent and catalyst. J. Mol. Catal. A Chem. 2006, 253, 165-169. [CrossRef]

6. Asghari, F.S.; Yoshida, H. Acid catalysed production of 5-hydroxymethyl furfural from d-Fructose in Subcritical Water. Ind. Eng. Chem. Res. 2006, 45, 2163-2173. [CrossRef]

7. Xu, H.; Miao, Z.; Zhao, H.; Yang, J.; Zhao, J.; Song, H.; Liang, N.; Chou, L. Dehydration of fructose into 5-hydroxymethylfurfural by high stable ordered mesoporous zirconium phosphate. Fuel 2015, 145, 234-240. [CrossRef]

8. Jain, A.; Shore, A.M.; Jonnalagadda, S.C.; Ramanujachary, K.V.; Mugweru, A. Conversion Of fructose, glucose and sucrose to 5-hydroxymethyl-2-furfural over mesoporous zirconium phosphate catalyst. Appl. Catal. A Gen. 2015, 489, 72-76. [CrossRef]

9. Kılıc, E.; Yılmaz, S. Fructose dehydration to 5-hydroxymethylfurfural over sulfated $\mathrm{TiO}_{2}-\mathrm{SiO}_{2}, \mathrm{Ti}-\mathrm{SBA}-15$, $\mathrm{ZrO}_{2}, \mathrm{SiO}_{2}$, and activated carbon catalysts. Eng. Chem. Res. 2015, 54, 5220-5225. [CrossRef]

10. Wang, S.; Zhang, Z.; Liu, B. Catalytic conversion of fructose and 5-hydroxymethylfurfural into 2,5-Furandicarboxylic acid over a recyclable $\mathrm{Fe}_{3} \mathrm{O}_{4}-\mathrm{CoO}_{x}$ magnetite nanocatalyst. ACS Sustain. Chem. Eng. 2015, 3, 406-412. [CrossRef]

11. Yang, Z.; Qi, W.; Huang, R.; Fang, J.; Su, R.; He, Z. Functionalized silica nanoparticles for conversion of fructose to 5-hydroxymethylfurfural. Chem. Eng. J. 2016, 296, 209-216. [CrossRef]

12. Morales, G.; Paniagua, M.; Melero, J.A.; Iglesias, J. Efficient production of 5-ethoxymethylfurfural from fructose by sulfonic mesostructured silica using DMSO as co-solvent. Catal. Today 2017, 279, 305-316. [CrossRef]

13. Hu, B.; Wang, K.; Wu, L.; Yu, S.H.; Antonietti, M.; Titirici, M.M. Engineering carbon materials from the hydrothermal carbonization process of biomass. Adv. Mater. 2010, 22, 813-828. [CrossRef] [PubMed] 
14. Wang, J.; Zhang, Y.; Wang, Y.; Zhu, L.; Cui, H.; Yi, W. Catalytic fructose dehydration to 5-hydroxymethylfurfural over sulfonated carbons with hierarchically ordered pores. J. Fuel Chem. Technol. 2016, 44, 1341-1348. [CrossRef]

15. Zhao, J.; Zhou, C.; He, C.; Dai, Y.; Jia, X.; Yang, Y. Efficient dehydration of fructose to 5 hydroxymethylfurfural over sulfonated carbon sphere solid acid catalysts. Catal. Today 2016, 264, 123-130. [CrossRef]

16. Wang, J.; Xu, W.; Ren, J.; Liu, X.; Lu, G.; Wang, Y. Efficient catalytic conversion of fructose into hydroxymethylfurfural by a novel carbon-based solid acid. Green Chem. 2011, 13, 2678-2681. [CrossRef]

17. Guo, F.; Fang, Z.; Zhou, T.J. Conversion of fructose and glucose into 5-hydroxymethylfurfural with lignin-derived carbonaceous catalyst under microwave irradiation in dimethyl sulfoxide-ionic liquid mixtures. Bioresour. Technol. 2012, 112, 313-318. [CrossRef] [PubMed]

18. Hu, L.; Tang, X.; Wu, Z.; Linc, L.; Xu, J.; Xu, N.; Dai, B. Magnetic lignin-derived carbonaceous catalyst for the dehydration of fructose into 5-hydroxymethylfurfural in dimethyl sulfoxide. Chem. Eng. J. 2015, 263, 299-308. [CrossRef]

19. De, S.; Dutta, S.; Patra, A.K.; Bhaumik, A.; Saha, B. Self-assembly of mesoporous $\mathrm{TiO}_{2}$ nanospheres via aspartic acid templating pathway and its catalytic application for 5-hydroxymethyl-furfural synthesis. J. Mater. Chem. 2011, 21, 17505-17510. [CrossRef]

20. Dutta, S.; De, S.; Patra, A.K.; Sasidharan, M.; Bhaumik, A.; Saha, B. Microwave assisted rapid conversion of carbohydrates into 5-hydroxymethylfurfural catalysed by mesoporous $\mathrm{TiO}_{2}$ nanoparticles. Appl. Catal. A Gen. 2011, 409-410, 133-139. [CrossRef]

21. Tamborini, L.H.; Casco, M.E.; Militello, M.P.; Silvestre-Albero, J.; Barbero, C.A.; Acevedo, D.F. Sulfonated porous carbon catalysts for biodiesel production: Clear effect of the carbon particle size on the catalyst synthesis and properties. Fuel Process. Technol. 2016, 149, 209-217. [CrossRef]

22. Liu, X.Y.; Huang, M.; Ma, H.L.; Zhang, Z.Q.; Gao, J.M.; Zhu, Y.L.; Han, X.J.; Guo, X.Y. Preparation of a carbon-based solid acid catalyst by sulfonating activated carbon in a chemical reduction process. Molecules 2010, 15, 7188-7196. [CrossRef] [PubMed]

23. Hou, Q.; Li, W.; Ju, M.; Liu, L.; Chen, Y.; Yang, Q. One-pot synthesis of sulfonated graphene oxide for efficient conversion of fructose into HMF. RCS Adv. 2016, 16, 104016-104024. [CrossRef]

24. Qi, X.; Guo, H.; Li, L.; Smith, R.L., Jr. Acid-catalyzed dehydration of fructose into 5-hydroxymethylfurfural by cellulose derived amorphous carbon. ChemSusChem 2012, 5, 2215-2220. [CrossRef] [PubMed]

25. Sevilla, M.; Fuertes, A.B. The production of carbon materials by hydrothermal carbonization of cellulose. Carbon 2009, 47, 2281-2289. [CrossRef]

26. Sun, Y.; Zhao, J.; Wang, J.; Tang, N.; Zhao, R.; Zhang, D.; Guan, G.; Li, K. Sulfur doped millimetre sized microporous activated carbon spheres derived from sulfonated poly(styrene-devinylbenzene) for $\mathrm{CO}_{2}$ capture. J. Phys. Chem. C 2017, 121, 10000-10009. [CrossRef]

27. Rao, C.N.R. Contribution to the infrared spectra of organosulphur compounds. Can. J. Chem. 1964, 42, 36-42. [CrossRef]

28. Yu, D.; Bo, B.; Yunhua, H. Fabrication of $\mathrm{TiO}_{2} @ y e a s t-c a r b o n$ hybrid composites with the raspberry like structure and their synergistic adsorption photocatalysis performance. J. Nanomater. 2013, 2013, 851417. [CrossRef]

29. Kansal, S.K.; Sood, S.; Umar, A.; Mehta, S.K. Photocatalytic degradation of Eriochrome Black T dye using well-crystalline anatase $\mathrm{TiO}_{2}$ nanoparticles. J. Alloys Compd. 2013, 581, 392-397. [CrossRef]

(C) 2019 by the authors. Licensee MDPI, Basel, Switzerland. This article is an open access article distributed under the terms and conditions of the Creative Commons Attribution (CC BY) license (http://creativecommons.org/licenses/by/4.0/). 